\title{
Evaluation of an Active Butanol Fraction Effects of Blighia Unijugata (Sapindaceae) Leaves on Some Biochemical Blood Parameters in Male Wistar Rats
}

\author{
N’DIA Kouadio Frédéric ${ }^{1 *}$, DIBY Yao Bernard ${ }^{2}$, KOUAKOU Kouakou Léandre ${ }^{1}$ and YAPO Angoué \\ Paul $^{1}$ \\ ${ }^{1}$ Laboratory of Physiology, Pharmacology and Pharmacopoeia, Nature Sciences Training and Research Unit, Nangui Abrogoua \\ University, Abidjan, Côte d'Ivoire \\ ${ }^{2}$ Laboratory of Agrovalorisation, Agroforestory Training and Research Unit, Jean Lorougnon GUEDE University, Daloa, Côte d'Ivoire \\ *Corresponding author: N’DIA Kouadio Frédéric, Laboratory of Physiology, Pharmacology and Pharmacopoeia, Nature Sciences \\ Training and Research Unit, Nangui Abrogoua University, PO Box 801 Abidjan 02, Côte d'Ivoire
}

\section{ARTICLE INFO}

Received: 蔧 November 22, 2021

Published: 絊 December 03, 2021

Citation: N'DIA Kouadio Frédéric, DIBY Yao Bernard, KOUAKOU Kouakou Léandre, YAPO Angoué Paul. Evaluation of an Active Butanol Fraction Effects of Blighia Unijugata (Sapindaceae) Leaves on Some Biochemical Blood Parameters in Male Wistar Rats . Biomed J Sci \& Tech Res 40(3)-2021. BJSTR. MS.ID.006440.

Keywords: Blighia Unijugata; Butanol Fraction ; Biochemical Parameters; Male Rat

\section{ABSTRACT}

Background and Objective: Blighia unijugata is usually used for its many therapeutic indications in Côte d'Ivoire. This study evaluated the effects of oral administration of an active butanol fraction of Blighia unijugata for 28 days on some biochemical blood parameters of male rats.

Materials and Methods: The active butanolic fraction of Blighia unijugata (BFBu) was prepared by successive liquid-liquid extractions of the total ethanolic extract of this plant with water, hexane, chloroform, ethyl acetate and n-butanol. Male albino rats (Rattus norvegicus) of Wistar strain were assigned into four groups of six animals each including a control group receiving distilled water and three test groups receiving $\mathrm{BFBu}$ at 50; 500 and $1000 \mathrm{mg} / \mathrm{kg}$ bw for 28 days respectively. The substances were administered orally, once a day. Blood samples were taken on days 7; 14; 21 and 28 of treatment by puncture at the level of the orbital sinus of the eye of rats previously anesthetized with ether for the determination of biochemical parameters using an automatic analyzer (KENZA MAX Biochemis Try, France). Biochemical analysis included creatinine, urea, total protein, transaminases (AST, ALT), total cholesterol, HDL-cholesterol, triglycerides, bilirubins (direct and indirect), glucose, electrolytes (sodium, potassium, chlorine, calcium, magnesium) and atherogenicity index.

Results: At repeated doses of 50, 500 and $1000 \mathrm{mg} / \mathrm{kg}$ bw for 28 days, the extract contributed to a significant increase in certain biochemical parameters such as AST, ALT, urea, creatinine, and total proteins. On the other hand, this same extract evaluated under the previous conditions, caused a decrease in the levels of glucose, total cholesterol, HDL-cholesterol, LDL cholesterol, bilirubins (direct and indirect) and had no noticeable effect on the variation in the concentration of certain electrolytes.

Conclusion: At high doses, the active butanol fraction of Blighia unijugata caused mid-term hepatic and renal toxicity. However, at a dose of $50 \mathrm{mg} / \mathrm{kg}$ bw, this fraction is non-toxic. This fraction has hypoglycemic effects and does not predispose rats to the risk of atherosclerosis and coronary heart disease. 


\section{Introduction}

Blighia unijugata (Sapindaceae), a species widespread in tropical and equatorial regions of Africa has been widely used for its multiple therapeutic properties [1]. In Côte d'Ivoire, Nigeria and Congo, this plant is abundantly consumed as vegetables and also used in the treatment of fever, nausea and vomiting, leprosy, eye pain, cough, migraines, rheumatism, kidney pain and joint stiffness, dizziness and especially high blood pressure [2,3]. However, despite the increased use of this medicinal plant, data-t-on its efficacy and safety are not yet available, thus exposing populations to all kinds of dangers. However, scientific studies and the rational evaluation of plants commonly used in traditional medicine could guarantee their best use, reduce the risk of accidents and allow the establishment of specific treatments for its poisonings [4]. Blighia unijugata has been the subject of several scientific publications due to its multiple uses in traditional medicine $[5,6]$. However, to our knowledge, very few scientific studies have been undertaken to establish the risks of toxicity of this plant on biochemical blood parameters. Previous work in our laboratory has shown that the butanolic fraction of Blighia unijugata (BFBu) has a significant hypotensive effect in rabbit of the species Oryctolagus cuniculus (Leporidae) compared to the other four fractions from the total ethanolic extract of this plant [7]. This study was therefore carried out to evaluate the effects of this active fraction on serum biochemical parameters of male Wistar rats.

\section{Materials and Methods}

\section{Materials}

Plant Material: The plant material consisted of powdered leaves of Blighia unijugata. The fresh leaves were collected in Abidjan (Cocody) in June 2009. This species was identified by us using available herbaria and a book written by [8]. The confirmation was made by the National Floristic Center (NFC) of Félix Houphouët-Boigny University (Abidjan, Ivory Coast) where a herbarium specimen has been kept under voucher $\mathrm{n}^{0165}$.

Animals: The experiments were carried out on 24 albino rats (Ratus norvegicus), healthy male, of Wistar strain, aged three months. Their average body weight was $148.00 \pm 7.07$ g. These animals came from the animal facility of the Institut Pasteur de Côte d'Ivoire located in Adiopodoumé (Abidjan) and were reproduced in the animal facility of the Laboratory of the Ecology Research Center of Nangui Abrogoua University (Côte d 'Ivoire) at an ambient temperature of $25 \pm 3{ }^{\circ} \mathrm{C}$. The photoperiod was 12 hours of light and 12 hours of darkness. Water and pellet food (Ivograin ${ }^{\circledR}$ ) were fed ad libitum to the rats before the experiment began. These animals were treated according to good laboratory practices [9].
Technical Material : The extraction equipment for the total ethanolic extract and fractions of Blighia unijugata consisted of an electric grinder (Culatti, France), an electronic scale (Mettler Toledo, PB 153-L, Switzerland), a magnetic stirrer (Stuart SB 162, UK), Buchner funnel, cotton wool and Wattman $n^{\circ} 1$ filter paper, Erlenmeyer flask, $500 \mathrm{~mL}$ conical flask, rotary evaporator (Büchi R110, Germany) and an oven (Retsch, Germany). The subacute toxicity study was performed using a gastric tube suitable for gavage of rats, pastor pipettes, and dry tubes. The analysis of the biochemical parameters was carried out using an automatic device (KENZA MAX Biochemis Try, France).

Solvents : The total ethanolic extract, hexanic, chloroform, ethyl acetate, butanolic and aqueous fractions of Blighia unijugata were obtained by extractions with different solvents (distilled water, 96\% ethanol, hexane, chloroform, ethyl acetate and n-butanol).

\section{Methods}

Preparation of the Total Ethanolic Extract of Blighia Unijugata : The total ethanolic extract of Blighia unijugata leaves was prepared according to the method of some authors [10]. The fresh leaves were thoroughly washed with tap water and then dried at room temperature. They were sprayed using an electric grinder (Culatti, France). Cold maceration was carried out with $100 \mathrm{~g}$ of powder in 2 liters of $96 \%$ ethanol, for $48 \mathrm{~h}$, with magnetic stirring. The resulting solution was first filtered through Buchner and then through Wattman $\mathrm{N}^{\circ} 1$ filter paper. This operation was repeated twice on the same powder residue. The filtrates obtained were added and concentrated under reduced pressure at $45{ }^{\circ} \mathrm{C}$ using a rotary evaporator (Büchi R110, Germany). The concentrated product, obtained after evaporation, was collected in a container and dried in an oven (Retsch, Germany) at $45{ }^{\circ} \mathrm{C}$ for $48 \mathrm{~h}$ according to the method described by [11]. The $13.3 \mathrm{~g}$ paste obtained corresponds to the total ethanolic extract (TEE) of Blighia unijugata. It was stored at $-5{ }^{\circ} \mathrm{C}$ in a hermetically sealed jar.

Preparation of Fractions of the Total Ethanolic Extract of Blighia Unijugata : Different fractions of the total ethanolic extract (TEE) were obtained by successive liquid-liquid extractions, with four solvents of increasing polarities (hexan, chloroform, éthyl acétate and n-butanol) according to the methods of $[12,13]$. Ten grams of the TEE was dissolved in $200 \mathrm{~mL}$ of hot distilled water $\left(45^{\circ} \mathrm{C}\right)$. The whole was homogenized by magnetic stirring for $15 \mathrm{~min}$ and then it was filtered. Aqueous filtrate obtained was exhausted for $10 \mathrm{~min}$ at $27 \pm 2{ }^{\circ} \mathrm{C}$ with $200 \mathrm{~mL}$ of hexane, thus giving two phases after decantation (hexan phase and residual aqueous phase). Residual aqueous phase was again treated for $10 \mathrm{~min}$ at 
$27 \pm 2{ }^{\circ} \mathrm{C}$ with $200 \mathrm{~mL}$ of chloroform to in turn give two phases (chloroform phase and residual aqueous phase). Same operation was successively treating the residual aqueous phase with ethyl acetate to also give an ethyl acetate phase and residual aqueous phase, then with n-butanol to finally obtain butanol phase and residual aqueous phase after settling. Each organic phases and the residual aqueous phase obtained was recovered and concentrated under reduced pressure throught a rotary evaporator (Büchi R110, Germany). Various concentrated products obtained were collected in containers and dried in an oven (Retsch, Germany) at $45^{\circ} \mathrm{C}$ for $24 \mathrm{~h}$ according to the method of some authors [14]. Thus, hexan (0.6 g), chloroform (1.1 g), ethyl acetate (1.6 g), butanol (3.18 g) and aqueous ( $3.12 \mathrm{~g}$ ) fractions were obtained. These end products were tested on rabbit blood pressure in the laboratory. Of these five fractions, butanol fraction coded BFBu had a greater hypotensive effect compared to the other four fractions. BFBu was therefore chosen for this study. The extractions were repeated several times in order to obtain a sufficient amount of extract to perform the tests. $\mathrm{BFBu}$ was stored at $-5^{\circ} \mathrm{C}$ in a tightly closed jar to prevent spoilage.

\section{Methods of the Study of Subacute Toxicity}

Preliminary Tests : The results of the acute oral toxicity study were used as the basis for the selection of the doses of BFBu that were administered to the rats. The initial dose level, selected on the basis of this orientation study, is well below the Maximum Tolerated Dose (MTD). At the end of these tests, the doses of 50; 500 and 1000 $\mathrm{mg} / \mathrm{kg}$ bw were chosen to be the doses to use during this study.

Distribution and Treatment of Rats : Animals were divided into 4 homogeneous batches of 6 rats. This homogeneity of the different batches is a function of the body weight of the rats. The tests were carried out on a control batch and 3 batches of treated animals. According to the method described by [15], each rat from the control group received by gavage distilled water at $10 \mathrm{~mL} /$ $\mathrm{kg}$ bw. Butanolic fraction (BFBu), diluted in distilled water was administered, by gavage, to each of the rats of the 3 test groups, respectively at doses of 50; 500 and $1000 \mathrm{mg} / \mathrm{kg}$ bw. Volume of FBu administered to the rats of each batch was less than $2 \mathrm{~mL}$. Rats were given distilled water or BFBu daily by gavage every morning between 7 and 8 hours AM. GMT for 28 days.

Blood Sample : Days 7, 14, 21 and 28 of treatment, blood samples were taken on an empty stomach from the rats previously anesthetized with ether for 2 to 3 minutes, by puncture at the level of the orbital sinus of the eye, at the level of the eye using pastor pipettes according to the technique described by [16-18]. Thus, 2 to $4 \mathrm{~mL}$ of blood from each animal of the 4 batches were collected in dry tubes.

Determination of Biochemical Parameters : Automatic device (KENZA MAX Biochemis Try, France) was used for determination of the biochemical parameters. Blood collected in dry tubes was centrifuged at $3000 \mathrm{rpm}$ for $10 \mathrm{~min}$ and the resulting serum was stored at $-20{ }^{\circ} \mathrm{C}$ until assaying for biochemical blood parameters. Creatinine, aspartate aminotransferase (AST) and alanine aminotransferase (ALT) were assayed by cinetic method [19]. Urea was determined by enzymatic method [19,20]. HDL (High Density Lipoprotein) Cholesterol Assay Method in VITROS HDL Plate is based on a non-HDL cholesterol precipitation technique followed by enzymatic detection [21]. Measurements of serum concentrations of total proteins, total cholesterol, triglycerides, bilirubins (direct and indirect) were carried out by the colorimetric method [19-23]. Glucose present in the serum was determined according to the glucose oxidase colorimetric method with the "Glucose Trinder GPO-POD" kit [20,24]. Finally, the electrolytes (magnesium, calcium, sodium, potassium and chlorine) were also determined by the colorimetric method [25-28].

\section{Evaluation of the Atherogenicity Index}

Atherogenicity index of rats was determined according to the formula of [29].

Atherogenicity index $=$ total cholesterol $/ H D L-$ cholesterol

\section{Statistical Analysis}

Statistical analysis of data and graphical representations were performed using Graph Pad Prism 5.01 software (San Diego, USA). The results obtained were expressed as the mean followed by the standard error of the mean $(\mathrm{M} \pm \mathrm{ESM})$. Difference between the mean values of the biochemical parameters was determined by one-way analysis of variance (ANOVA 1) and supplemented by Tukey's test for the comparison of the means of the parameters of the different test groups compared to the control group. The significance level was set at $\mathrm{p}<0.05$.

\section{Results}

\section{Effects of Bfbu on Biochemical Parameters}

Effect of Bfbu on Creatinine Level : The mean creatininemie of the treated batch with $\mathrm{BFBu}$ at $50 \mathrm{mg} / \mathrm{kg}$ bw is lower than that of the control from $D_{7}$ to $D_{21}$ with the exception of $D_{28}$ where it is higher than that of the control. D7, the creatinine level of the treated batch with BFBu at $500 \mathrm{mg} / \mathrm{kg}$ bw is lower than that of the control. However, from $\mathrm{D}_{14}$, this rate increases until the end of this study with a significantly $(\mathrm{p}<0.05)$ high rate with a value of $8.17 \pm 0.48$ $\mathrm{mg} / \mathrm{L}$ on $\mathrm{D}_{28}$. Only the creatinine level of the batch treated with $\mathrm{BFBu}$ at $1000 \mathrm{mg} / \mathrm{kg}$ bw increased throughout this study. This increase of $8.67 \pm 0.33 \mathrm{mg} / \mathrm{L}$ is significant $(\mathrm{p}<0.01)$ on the $28^{\text {th }}$ day of treatment compared to the creatinine level of the control batch which is $6.17 \pm 0.60 \mathrm{mg} / \mathrm{L}$ (Figure $1 \mathrm{~A}$ ). 

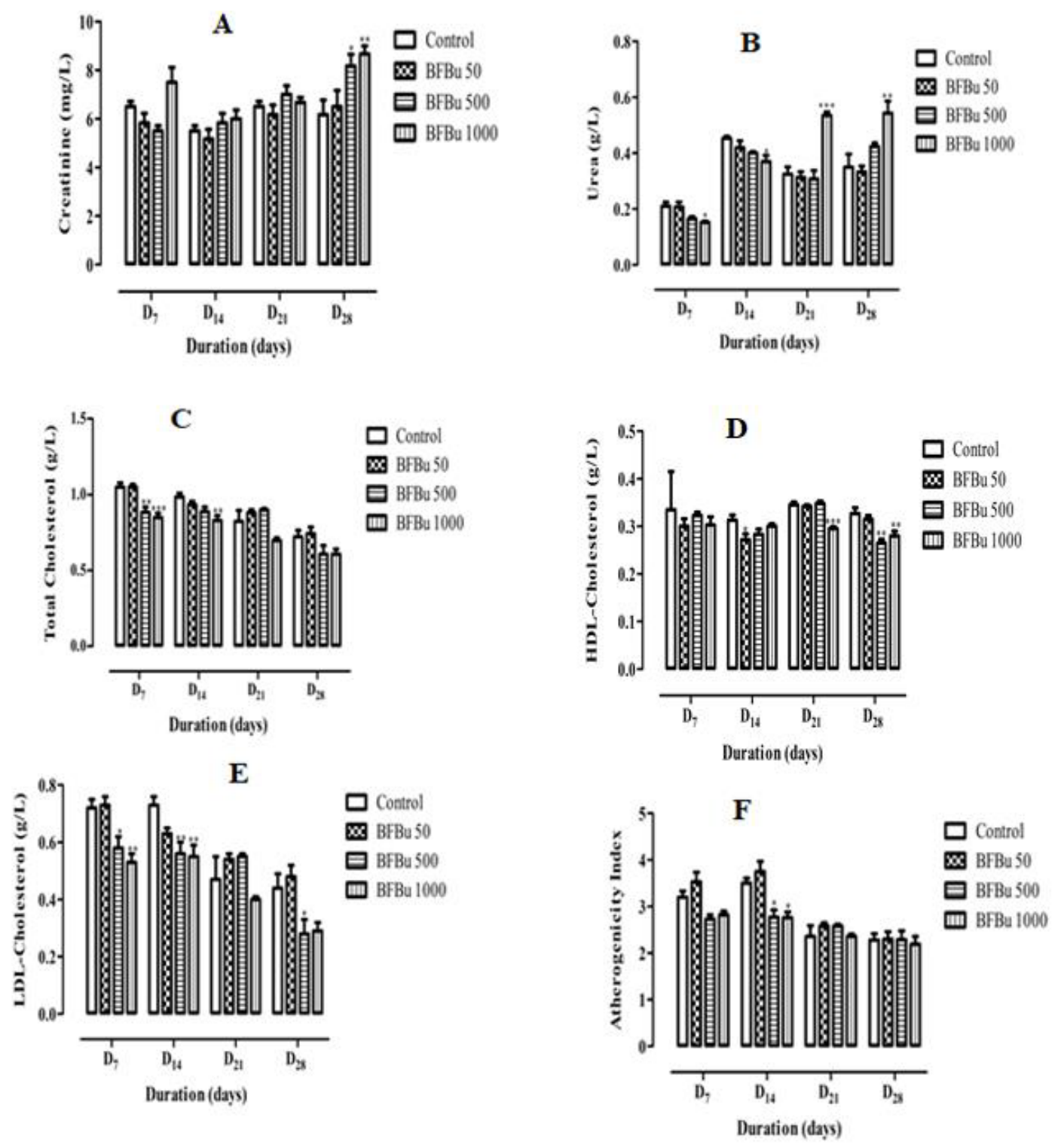

Figure 1: Effect of Bfbu on Some Biochemical Blood Parameters and Atherogenicity Index.

Note: ${ }^{*} \mathrm{p}<0.05 ;{ }^{* *} \mathrm{p}<0.01 ;{ }^{* * *} \mathrm{p}<0.001 ; \mathrm{n}=6$ : Differences were significant when values of treated groups with BFBu were compared to that of control group, at the same corresponding day.

Effect of Bfbu on the Urea Rate: In the treated batches with $\mathrm{BFBu}$ at 50 and $500 \mathrm{mg} / \mathrm{kg}$ bw, the urea levels decreased compared to the control during this study, with the exception of $\mathrm{D}_{28}$ where there was an increase in this level. However, this decrease remains insignificant throughout this study. Moreover, from $\mathrm{D}_{7}$ to $\mathrm{D}_{14}$, in the treated batch with BFBu at $1000 \mathrm{mg} / \mathrm{kg}$ bw, a significant drop $(\mathrm{p}<0.05)$ in the urea level was noted compared to the control. Rate decreases and passes respectively from $0.21 \pm 0.02 \mathrm{~g} / \mathrm{L}$ to $0.15 \pm 0.0$ $\mathrm{g} / \mathrm{L}$ and from $0.45 \pm 0.01 \mathrm{~g} / \mathrm{L}$ to $0.37 \pm 0.02 \mathrm{~g} / \mathrm{L}$. However, from the 21st day of treatment, the amount of urea increased significantly ( $p<0.01-0.001)$ in this batch compared to the control batch. The urea rate increases and goes from $0.33 \pm 0.03 \mathrm{~g} / \mathrm{L}$ to $0.54 \pm 0.01 \mathrm{~g} / \mathrm{L}$ on $\mathrm{D}_{21}$ and from $0.35 \pm 0.04 \mathrm{~g} / \mathrm{L}$ at $0.54 \pm 0.04 \mathrm{~g} / \mathrm{L}$ on $\mathrm{D}_{28}$ (Figure $1 \mathrm{~B}$ ).

Effect of Bfbu on Total Cholesterol Level: Total cholesterol level of the treated batch with BFBu at $50 \mathrm{mg} / \mathrm{kg}$ body weight is lower than that of the control on $\mathrm{D}_{7}$ and $\mathrm{D}_{14}$. However, from $\mathrm{D}_{21}$, this rate undergoes a non-significant increase compared to the control. Moreover, the treated batches with BFBu at 500 and $1000 \mathrm{mg} / \mathrm{kg}$ 
bw, the total cholesterol level decreased during this study with the exception of the treated batch with BFBu at $500 \mathrm{mg} / \mathrm{kg}$ bw where this rate increased on $D_{21}$. This decrease in mean cholesterolemia is significant $(\mathrm{p}<0.01-0.001)$ on $\mathrm{D}_{7}$ and $\mathrm{D}_{14}$ respectively compared to the mean value of the cholesterol level in the control batch, but it normalizes from $\mathrm{D}_{21}$. The cholesterol level decreases from $1.05 \pm 0.03 \mathrm{~g} / \mathrm{L}$ to $0.85 \pm 0.03 \mathrm{~g} / \mathrm{L}$ on $\mathrm{D}_{7}$ and from $0.99 \pm 0.03 \mathrm{~g} / \mathrm{L}$ to $0.83 \pm 0,03 \mathrm{~g} / \mathrm{L}$ on $\mathrm{D}_{14}$ (Figure $1 \mathrm{C}$ ).

Effect of Bfbu on Hdl-Cholesterol Levels: The mean HDL cholesterol values of the batch of rats treated with BFBu at $50 \mathrm{mg} /$ $\mathrm{kg}$ bw remained lower than that of the control during this study with a significant decrease $(p<0.05)$ from a value of $0.27 \pm 0.01 \mathrm{~g} / \mathrm{L}$ on $\mathrm{D}_{14}$. As for the HDL cholesterol level in the batch of rats treated with $\mathrm{BFBu}$ at $500 \mathrm{mg} / \mathrm{kg}$ bw, a decrease was noted during this work with the exception of $D_{21}$ where its mean value is similar to that of the control. The mean value drops significantly $(\mathrm{p}<0.01)$ from $0.33 \pm 0.01 \mathrm{~g} / \mathrm{L}$ to $0.27 \pm 0.01 \mathrm{~g} / \mathrm{L}$ on $\mathrm{D}_{28}$ at this dose. Finally, in the batch treated with BFBu at $1000 \mathrm{mg} / \mathrm{kg}$ bw, the level of HDL cholesterol decreased throughout this study with a significant drop $(\mathrm{p}<0.001-0.01)$ in this value which went from $0.35 \pm 0.01 \mathrm{~g} / \mathrm{L}$ at $0.30 \pm 0.00 \mathrm{~g} / \mathrm{L}$ and from $0.33 \pm 0.01 \mathrm{~g} / \mathrm{L}$ to $0.28 \pm 0.01 \mathrm{~g} / \mathrm{L}$ respectively on $\mathrm{D}_{21}$ and $\mathrm{D}_{28}$ after administration of BFBu (Figure $1 \mathrm{D}$ ).

Effect of BFBu on LDL-Cholesterol Levels: In the treated batch with BFBu at $50 \mathrm{mg} / \mathrm{kg}$ bw, the LDL-cholesterol level did not undergo any significant variation from $\mathrm{D}_{7}$ to $\mathrm{D}_{28}$ compared to that of the control batch In the treated batches with BFBu at 500 and 1000 $\mathrm{mg} / \mathrm{kg}$ bw, the level of LDL-cholesterol decreased during this study. This drop is significant $(\mathrm{p}<0.05-0.01)$ on $\mathrm{D}_{7}$ and $\mathrm{D}_{14}$ in these two batches. From $\mathrm{D}_{21}$, BFBu does not cause any significant variation in the LDL cholesterol level with the exception of the treated batch with $\mathrm{FBu}$ at $500 \mathrm{mg} / \mathrm{kg}$ of bw where a significant drop $(\mathrm{p}<0.05)$ in this level was recorded on $\mathrm{D}_{28}$ with a value of $0.28 \pm 0.05 \mathrm{~g} / \mathrm{L}$ (Figure 1E).

Evaluation of the Atherogenicity Index of BFBu: At a dose of $50 \mathrm{mg} / \mathrm{kg}$ bw, BFBu did not cause any significant increase in the atherogenicity index compared to that of the control group during this study. In the treated batch with BFBu at $500 \mathrm{mg} / \mathrm{kg}$ bw, there was a non-significant decrease on $\mathrm{D}_{7}$ followed by a significant decrease $(p<0.05)$ in this index on $D_{14}$ with a value of $2.77 \pm 0.16$. From $D_{21}$ to $D_{28}$, the atherogenicity index of this batch remains similar to that of the control batch. Finally, in the treated batch with $\mathrm{BFBu}$ at $1000 \mathrm{mg} / \mathrm{kg} \mathrm{bw}$, the atherogenicity index remained low throughout this study compared to the mean value of the control batch. This drop is significant $(\mathrm{p}<0.05)$ on $\mathrm{D}_{14}$ where the mean value is $2.76 \pm 0.12$ (Figure $1 \mathrm{~F}$ ).

Effect of $\mathrm{BFBu}$ on Triglyceride Levels: Repeated administration of BFBu at $50 \mathrm{mg} / \mathrm{kg}$ bw causes a non-significant decrease in the triglyceride level on $\mathrm{D}_{7}$ followed by an increase in this level from $\mathrm{D}_{14}$ until the end of this study. In the presence of BFBu at $500 \mathrm{mg} / \mathrm{kg} \mathrm{bw}$, the triglyceride level increases during this study with a significant increase $(\mathrm{p}<0.01-0.05)$ respectively on the $7^{\text {th }}$ and $14^{\text {th }}$ day of treatment. The respective average values recorded are $0.66 \pm 0.05 \mathrm{~g} / \mathrm{L}$ and $0.50 \pm 0.01 \mathrm{~g} / \mathrm{L}$. In the treated batch with BFBu at $1000 \mathrm{mg} / \mathrm{kg} \mathrm{bw}$, a significant increase $(\mathrm{p}<0.01-0.001)$ in the level of triglycerides was noted respectively on $\mathrm{D}_{7}$ and $\mathrm{D}_{14}$ where the average levels are $0.64 \pm 0.01 \mathrm{~g} / \mathrm{L}$ and $0.56 \pm 0.02 \mathrm{~g} / \mathrm{L}$. This increase is followed by a non-significant drop in triglyceridemia compared to the control batch on $\mathrm{D}_{21}$ and $\mathrm{D}_{28}$ (Figure $2 \mathrm{~A}$ ).

Effect of BFBu on Total Protein Level: Total protein level of the treated batch with BFBu at $50 \mathrm{mg} / \mathrm{kg}$ bw remained almost lower than that of the control during this study with the exception of $\mathrm{D}_{28}$ where this rate increased from $46.80 \pm 0.95 \mathrm{~g} / \mathrm{L}$ at $48.70 \pm 1.05$ $\mathrm{g} / \mathrm{L}$. Variations caused by $\mathrm{BFBu}$ at this dose are not significant $(p \geq 0.05$ ) compared to the control batch. In the treated batches with $\mathrm{BFBu}$ at 500 and $1000 \mathrm{mg} / \mathrm{kg}$ bw, an increase in this rate was noted throughout this work. This increase is significant $(p<0.05)$ in the treated batch with $\mathrm{BFBu}$ at $500 \mathrm{mg} / \mathrm{kg}$ bw from $\mathrm{D}_{14}$. The increase in total protein level caused by BFBu at $1000 \mathrm{mg} / \mathrm{kg}$ bw is only significant $(\mathrm{p}<0.001)$ on the 14 th day of treatment where its value is $61.50 \pm 0.43 \mathrm{~g} / \mathrm{L}$ (Figure 2B).

Effect of BFBu on Alanine Aminotransferase Level: Alanine aminotransferase (ALT) level of the treated batches with BFBu at 50 and $500 \mathrm{mg} / \mathrm{kg}$ bw is lower than that of the control batch on $\mathrm{D}_{7}$. However, from $\mathrm{D}_{14}$ until the end of this study, the level of ALT increased in these batches compared to that of the control batch. The increase in this level in the treated batch with BFBu at 500 $\mathrm{mg} / \mathrm{kg}$ bw is significant $(\mathrm{p}<0.001)$ from this period, whereas the increase in this rate is only exceptionally so on the 14 th day in the lot treated with $\mathrm{BFBu}$ at $50 \mathrm{mg} / \mathrm{kg}$ bw where its value is $138 \pm 6.63$ IU/L. In the treated batch with BFBu at $1000 \mathrm{mg} / \mathrm{kg}$ bw, the level of ALT, which remained almost the same to the control on $D_{7}$, underwent a significant increase $(\mathrm{p}<0.001)$ from $\mathrm{D}_{14}$ to $\mathrm{D}_{28}$ with values of $165 \pm 2.63 \mathrm{IU} / \mathrm{L}\left(\mathrm{J}_{14}\right), 213 \pm 3.62 \mathrm{IU} / \mathrm{L}\left(\mathrm{J}_{21}\right)$ and $265 \pm 9.56$ $\mathrm{IU} / \mathrm{L}\left(\mathrm{J}_{28}\right)$ (Figure $2 \mathrm{C}$ ).

Effect of BFBu on Aspartate Aminotransferase Level: On $D_{7}$ all the doses of BFBu tested caused a significant decrease $(p<0.05-$ 0.001 ) in the level of aspartate aminotransferase (AST) compared to the control. The mean AST value of the control batch is $188 \pm 7.92$ IU/L. The AST levels recorded are $128 \pm 6.94 \mathrm{IU} / \mathrm{L}, 145 \pm 11.00 \mathrm{IU} / \mathrm{L}$ and $155 \pm 2.79 \mathrm{IU} / \mathrm{L}$ respectively for doses of BFBu of 50, 500 and $1000 \mathrm{mg} / \mathrm{kg}$ bw. However, from $\mathrm{D}_{14}$, an increase in the AST rate was recorded in all the batches treated with $\mathrm{BFBu}$. This increase was not significant in all of the batch test from $\mathrm{D}_{14}$ to $\mathrm{D}_{21}$. On $\mathrm{D}_{28}$, in the treated batches with BFBu at 500 and $1000 \mathrm{mg} / \mathrm{kg} \mathrm{bw}$, a significant 
increase $(\mathrm{p}<0.01)$ in its mean value was recorded compared to that of the control batch (Figure 2D).

Effect of BFBu on Total Bilirubin Level: All tested doses of $\mathrm{BFBu}$, the mean values of the total bilirubin level underwent a nonsignificant decrease $(\mathrm{p} \geq 0.05)$ compared to that of the control lot during this study with the exception of the lot treated with BFBu at $1000 \mathrm{mg} / \mathrm{kg}$ bw on $\mathrm{D}_{7}$ where this rate, a value of $9.50 \pm 0.34 \mathrm{mg} / \mathrm{L}$, remained almost identical to that of the control (Figure 2E).

Effect of BFBu on Conjugated Bilirubin Level: With regard to the level of conjugated bilirubin, the mean values in the presence of all the doses of BFBu tested are lower than that of the control during this study. At $50 \mathrm{mg} / \mathrm{kg}$ bw, a significant drop ( $\mathrm{p}<0.01-0.001$ ) in the conjugated bilirubin level was recorded on $\mathrm{D}_{14}$ and $\mathrm{D}_{28}$, respectively, but this decrease was not significant on $D_{7}$ and $D_{21}$. At $500 \mathrm{mg} / \mathrm{kg}$ bw, the conjugated bilirubin level underwent a significant decrease ( $p<0.05-0.001$ ) from the $14^{\text {th }}$ day of treatment with the exception of $\mathrm{D}_{7}$ where this decrease is not significant with a value of $0.55 \pm 0.08$ $\mathrm{mg} / \mathrm{L}$. Finally, at $1000 \mathrm{mg} / \mathrm{kg}$ bw, the level of conjugated bilirubin decreases significantly ( $p<0.05-0.001$ ) during the treatment except on $\mathrm{D}_{21}$ when a non-significant drop in its value compared to the control was recorded. (Figure 2F).
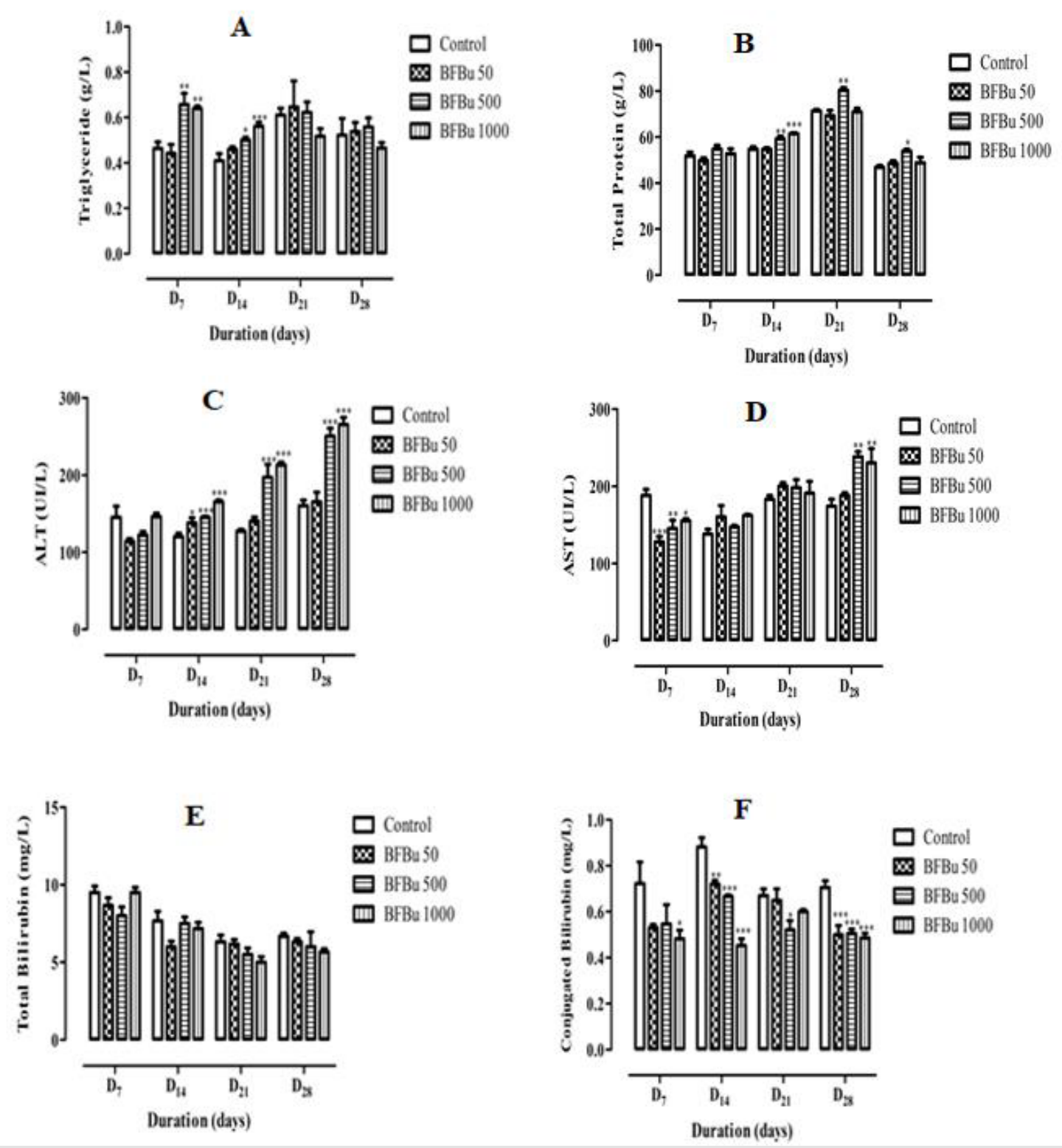

Figure 2: Effect of Bfbu on Some Biochemical Blood Parameters.

Note: * $\mathrm{p}<0.05$; ** $\mathrm{p}<0.01$; *** $\mathrm{p}<0.001 ; \mathrm{n}=6$ : Differences were significant when values of treated groups with BFBu were compared to that of control group, at the same corresponding day. 
Effect of BFBu on Glucose Level: No significant variation in blood glucose was recorded in the treated batches with $\mathrm{BFBu}$ at 50 and $500 \mathrm{mg} / \mathrm{kg}$ bw compared to the control during this study. On the $7^{\text {th }}$ and $14^{\text {th }}$ day of treatment, the mean values of the blood glucose level underwent a significant increase $(p<0.05)$ in the treated batch with $\mathrm{BFBu}$ at $1000 \mathrm{mg} / \mathrm{kg}$ bw compared to the control batch. The average blood sugar values are $1.00 \pm 0.06 \mathrm{~g} / \mathrm{L}$ $\left(D_{7}\right)$ and $0.85 \pm 0.02 \mathrm{~g} / \mathrm{L}\left(\mathrm{D}_{14}\right)$. However, from the $21^{\text {st }}$ to the $28^{\text {th }}$ day of treatment, a significant decrease $(p<0.05-0.001)$ in the blood glucose of the rats was observed in the treated batch with $\mathrm{FBu}$ at $1000 \mathrm{mg} / \mathrm{kg}$ bw compared to the mean value of the glycemia of the rats of the control group (Figure 3).

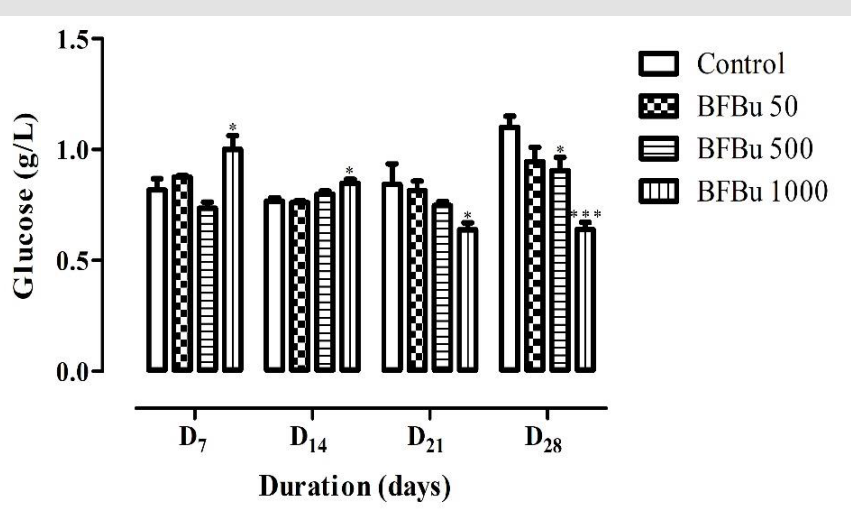

Figure 2: Effect of Bfbu on Glucose Levels.

Note: ${ }^{*} \mathrm{p}<0.05 ;{ }^{* *} \mathrm{p}<0.01 ;{ }^{* * *} \mathrm{p}<0.001 ; \mathrm{n}=6$ : Differences were significant when values of treated groups with BFBu were compared to that of control group, at the same corresponding day.

\section{Effects of BFBu on Electrolytes}

Effect of BFBu on Sodium Level: Repeated administration of BFBu at doses of 50, 500 and $1000 \mathrm{mg} / \mathrm{kg}$ bw did not impacted with sodium levels during this study with the exception of the batch treated with BFBu at $1000 \mathrm{mg} / \mathrm{kg}$ bw where an increase significant $(p<0.05)$ was recorded on the 28th day of treatment compared to the control batch. The sodium level is $143 \pm 1.31 \mathrm{meq} / \mathrm{L}$ at this dose (Figure 4A).

Effect of BFBu on Potassium Level: At $50 \mathrm{mg} / \mathrm{kg}$ bw, BFBu induces a drop in the potassium level with the exception of $\mathrm{D}_{28}$ where this rate increased compared to the control. These variations are not significant at this dose. At a dose of $500 \mathrm{mg} / \mathrm{kg}$ bw, the potassium level is lower than that of the control during this study. The drop in this rate is significant $(\mathrm{p}<0.001)$ on the $14^{\text {th }}$ day of treatment in this batch where a value of $3.30 \pm 0.10 \mathrm{meq} / \mathrm{L}$ was recorded. However, on $\mathrm{D}_{21}$, the potassium level is higher than that of the control. As for the treated batch with BFBu at $1000 \mathrm{mg} / \mathrm{kg}$ bw, the potassium level remained lower than that of the control during this study with significant decreases $(p<0.05-0.001)$ noted respectively on $\mathrm{D}_{7}$ and $\mathrm{D}_{14}$ but not significant of $\mathrm{D}_{21}$ to $\mathrm{D}_{28}$ compared to the control batch (Figure 4B).
Effect of BFBu on Chlorine Level: Chlorine level of the treated batch with BFBu at $50 \mathrm{mg} / \mathrm{kg}$ bw decreased significantly $(\mathrm{p}<0.05)$ on $\mathrm{D}_{14}$ compared to the control batch. As for the treated batches with BFBu at 500 and $1000 \mathrm{mg} / \mathrm{kg}$ bw, the chlorine level increased during this study with exceptionally significant increases ( $p<0.01-0.001$ ) in this rate on $\mathrm{D}_{28}$ compared to the control batch. The respective values recorded at these doses are $122 \pm 3.53 \mathrm{meq} / \mathrm{L}$ and $119 \pm 1.50 \mathrm{meq} / \mathrm{L}$. However, on $\mathrm{D}_{21}$, the chlorine level is almost identical in all the batches treated with BFBu (Figure 4C).

Effect of BFBu on Calcium Levels: The calcium level of the treated batches with BFBu at 50, 500 and $1000 \mathrm{mg} / \mathrm{kg}$ bw did not undergo any significant variation $(\mathrm{p} \geq 0.05)$ during this study compared to the control (Figure 4D).

Effect of BFBu on the Magnesium Level: $O n D_{7}$, the magnesium level of the treated batches with BFBu at 50 and 500 $\mathrm{mg} / \mathrm{kg}$ bw is higher than that of the control. However, from the $14^{\text {th }}$ day of treatment, this rate decreased in these batches compared to the control. Only the magnesium level of the treated batch with $\mathrm{FBu}$ at $1000 \mathrm{mg} / \mathrm{kg}$ bw continuously decreased during this work. All the variations caused by $\mathrm{BFBu}$ at the doses tested remained insignificant $(\mathrm{p} \geq 0.05)$ compared to the control during this study (Figure 4E). 

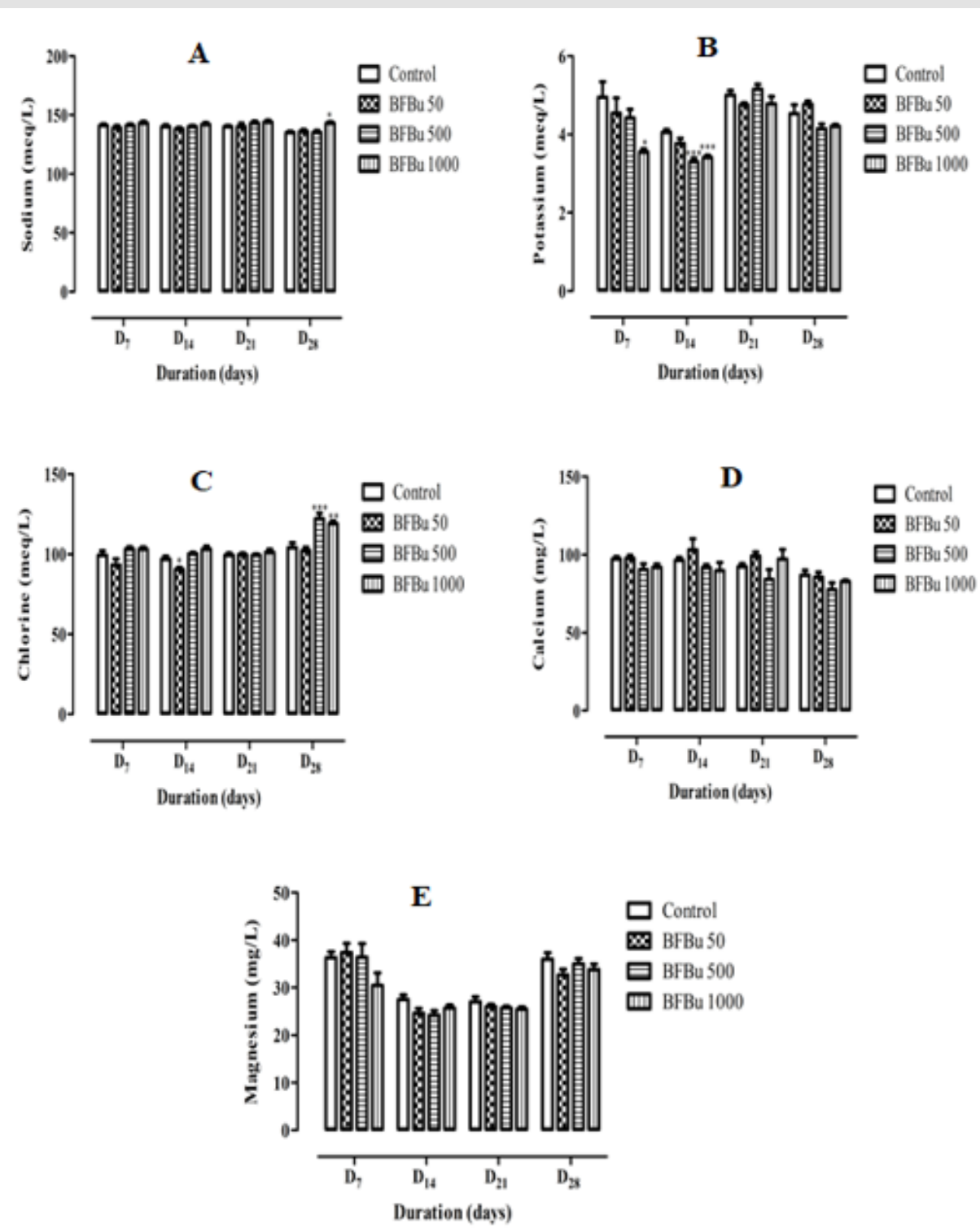

Figure 4: Effect of Bfbu on Electrolytes.

Note: $\mathrm{p}>0.05 ; \mathrm{n}=6$ : non-significant difference compared to the control batch

${ }^{*} \mathrm{p}<0.05 ;{ }^{* *} \mathrm{p}<0.01 ;{ }^{* * *} \mathrm{p}<0.001 ; \mathrm{n}=6$ : Differences were significant when values of treated groups with BFBu were compared to that of control group, at the same corresponding day.

\section{Discussion}

The various biochemical parameters examined in this study are useful indicators for assessing the toxicity of plant extracts in animals [30]. Analysis of blood parameters is relevant in risk assessment since changes in the hematologic system have a very high predictive value for toxicity in humans [31]. The significant reduction in the level of transaminases (AST and ALT) observed at the start of the experiments indicates that the absorption of $\mathrm{BFBu}$ does not cause cytolysis but rather a protective effect in the liver. BFBu does not harm the liver within the first week of administration. However, at the end of this study, the increase in these parameters following the administration of BFBu could be due to the appearance of necrosis in one or more organs, namely the liver, heart and kidneys, thus causing an increase in the level of these enzymes in the blood. Indeed, according to [32], damaged tissue is generally associated with the release of specific enzymes from the tissue, or the affected organ, into the bloodstream. The consequence is an increase in the activity of such enzymes in bodily secretions. ALT is a cytoplasmic enzyme found in very high concentrations in the liver, and an increase in this specific enzyme suggests liver cell damage while AST is less specific than ALT as an indicator of liver function. 
The increase in the level of transaminases (ALT and AST) has also been observed in liver disorder [33-36]. These results are in agreement with those of $[37,38]$ who reported that the ethanolic and methanolic extracts of Alchornia cordifolia leaves cause an increase in the activity of transaminases. These authors therefore suggested that these extracts exhibit hepatotoxic effects at doses of 250 to $500 \mathrm{mg} / \mathrm{kg}$ bw and 800 to $1600 \mathrm{mg} / \mathrm{kg} \mathrm{bw}$, respectively. $\mathrm{BFBu}$ would therefore be, at the tested doses of 500 and $1000 \mathrm{mg} /$ $\mathrm{kg}$ bw and in the long term, probably poorly tolerated by the liver. According to [39], the increase in the serum total protein level is an indication of tissue damage while the significant decrease in the total protein content of the liver is a reflection of hepatic nontoxicity. The significant increase in the total protein content in the batches of rats treated with BFBu at 500 and $1000 \mathrm{mg} / \mathrm{kg}$ bw could therefore indicate an increase in protein stores and therefore suggest hepatic toxicity, which would again confirm the detrimental effects of BFBu at 500 and $1000 \mathrm{mg} / \mathrm{kg}$ bw. Bilirubin, a metabolic breakdown product of heme derived from senescent red blood cells, is also one of the most commonly used tests for liver function. Its concentration could indicate the condition of the liver and the type of liver damage $[40,41]$.

The significant reduction in total and conjugated bilirubin levels could be provided by a deficiency in the secretory function of these proteins. Certain substances present in FBu could therefore imply inhibitions at the level of the hepatic cells. This reduction can also affect the functional activity of the liver. Doses of BFBu of 50 and $500 \mathrm{mg} / \mathrm{kg}$ bw did not significantly affect blood sugar. Only the dose of $1000 \mathrm{mg} / \mathrm{kg}$ bw increased it on $\mathrm{D}_{7}$ and $\mathrm{D}_{14}$ and decreased on $\mathrm{D}_{21}$ and $\mathrm{D}_{28}$. These results suggest that this fraction has hyperglycaemic activity followed by hypoglycaemic activity at high doses. At the end of this study, the hypoglycaemic activity could be attributed to the existence of the molecules demonstrated in this fraction. Indeed, flavonoids from different plants have shown a promising hypoglycemic effect in diabetic animal models [42-44]. Saponins are triterpene, steroidal or alkaloidic glycosides. Authors have shown a hypoglycemic activity of triterpene glycosides $[45,46]$.

It is therefore possible that the presence of flavonoids and saponins in FBu could be responsible for the hypoglycemic effects of this fraction. Some authors reported a significant decrease $(p<0.05)$ in the fasting blood glucose level of rats made diabetic with alloxane when given the ethanolic extract of Ficus microcarpa, orally for two weeks [47].

Finally, these results are in agreement with the studies conducted respectively on the seed cotyledon and leaves of Chrysophyllum albidum at doses between 250 and $1000 \mathrm{mg} / \mathrm{kg} \mathrm{bw}$ $[48,49]$ on the one hand, and on the other hand on Bixin $(10 \mathrm{mg} / \mathrm{kg}$ bw) extracted from the seeds of Bixa orellana [50]. These authors have shown that these extracts significantly decrease the glucose level in normal and diabetic rats induced by alloxane. However, the notable increase in blood sugar observed in this study could be linked mainly to the stress undergone by the animals at the time of sampling as suggested by [51] during work with Momordica charantia in rabbits. However, a real hypoglycemic effect could be attributed to this fraction by carrying out further study on suitable models. The significant $(\mathrm{p}<0.01)$ increase in mean serum creatinine was seen in the lots that received the highest doses of FBu $(500$ and $1000 \mathrm{mg} / \mathrm{kg} \mathrm{bw}$ ). This result suggests that BFBu is toxic to the kidneys. Creatinine is the major catabolic product of muscles and is secreted by the kidneys. Serum creatinine levels are used as an indicator of kidney defects $[38,52,53]$.

The significant drop in the urea level observed at the start of treatment in the batch treated with FBu at $1000 \mathrm{mg} / \mathrm{kg}$ bw would be a sign of the good functioning of the kidney and the lack of renal toxicity due to this fraction. However, the increase in this level in this batch would be an indication of azotemia. According to Nduka [54], the high urea level is associated with the increased catabolism of tissue proteins. The excess protein in the blood collapses and urea excretion decreases, increasing its level in the blood. The increase in this level would also be a sign of damage to the kidney, which can no longer extract nitrogenous excretion products from the blood and concentrate them in the urine, thus confirming the renal toxicity caused by BFBu. Other indicators of kidney function such as sodium, potassium and chlorine were significantly affected by BFBu except calcium and magnesium which were not. The urea, sodium and chlorine levels significantly increased in the treated batches with BFBu at the highest doses during this study.

These results probably suggest nephrotoxicity of BFBu at high doses, which would support the hypothesis made about the increased creatinine level. However, the lack of a significant effect of BFBu on serum calcium and magnesium concentrations in animals suggests that the secretory capacity of the kidney and normal organ function related to these parameters were not affected. According to the work of [41] on the aqueous extract of Felicia muricata at doses of 50,100 and $200 \mathrm{mg} / \mathrm{kg}$ bw, the calcium and magnesium levels of the rats were not significantly modified. The hypokalaemia caused by repeated administration of BFBu may be due to an alteration in tubular reabsorption of potassium. Similar effects have been reported by [55] with the aqueous extract of Arctotis arctotoides on the decrease in potassium concentration. These authors suggested that this plant would not cause any damage to the cardiovascular system, which could also be the case with BFBu. Changes in the concentration of major lipids such as total cholesterol, HDL-cholesterol, LDL-cholesterol, and triglycerides, as well as the atherogenicity index may provide useful information on lipid metabolism and heart predisposition, atherosclerosis and its associated coronary heart disease [29,56- 
58]. In this study, the decrease in serum cholesterol level could be explained by the deterioration of cholesterol biosynthesis. This has also been suggested by [59] who showed that the aqueous extract of Chrysocoma ciliata at doses of 50, 100 and $200 \mathrm{mg} / \mathrm{kg}$ body weight decreases the cholesterol level in rats. Elevated cholesterol concentration is an important risk factor for cardiovascular disease [60].

Therefore, lowering cholesterol at the doses of BFBu tested could be clinically beneficial as this fraction is unlikely to be associated with cardiovascular risk. Triglycerides are the storage forms of fatty acids. The decrease in the level of lipids such as HDL and LDL cholesterols as well as the decrease in the atherogenicity index may be an indication that FBu would not predispose animals to the risk of atherosclerosis and associated coronary heart disease. According to several authors, the total cholesterol/cholesterolHDL ratio constitutes a revealing index of arterial and especially coronary risk. This ratio would indicate an increased risk if it is greater than 4.4 [29]. However, according to the results obtained during this study, the atherogenicity index of each animal was lower than this value. BFBu could therefore be protective of heart tissue. Furthermore, the decrease in serum lipid parameters investigated in this study suggests that the lipid metabolism of animals was disturbed by the administration of BFBu. This disturbance could be an indication that BFBu would probably not predispose the animal to atherosclerosis and associated coronary heart disease despite the notable elevation $(p<0.001)$ in triglyceride levels during the first 14 days in batches treated with BFBu at 500 and $1000 \mathrm{mg} /$ kg bw.

\section{Conclusion}

This study showed that butanol fraction of Blighia unijugata (BFBu) produced changes in biochemical parameters following repeated administration. $\mathrm{BFBu}$ caused disruption of the carbohydrate, lipid and protein balances. Athigh doses, BFBu caused hepatic and renal toxicity. However, the fraction tested at dose of $50 \mathrm{mg} / \mathrm{kg} \mathrm{bw}$, is non-toxic. This fraction has hypoglycemic effects and could be used in the management of diabetes, respectively. $\mathrm{BFBu}$ would not predispose rats to the risk of atherosclerosis and associated coronary heart disease.

\section{Conflict of Interest}

The authors declare no conflict of interest.

\section{References}

1. Hyde MA, Wursten B (2002) Flora of Zimbabwe: Species information: Blighia unijugata. CITIS Ed, Harare, pp. 317-318.

2. Adjanohoun E, Aké Assi L (1979) Contribution au recensement des plantes médicinales de Côte d'Ivoire. Centre National de Floristique, Abidjan, Côte d'Ivoire, pp. 272-274.
3. Burkill HM (2000) The useful plants of West tropical Africa ( $\left.2^{\text {nd }} E d n.\right)$, Volume 5, Families S-Z, Addenda Royal Botanic Gardens, Kew, United Kingdom; Richmond, p. 11-13.

4. Gies JP (1993) Bases de pharmacologie moléculaire. Ed. Marketing, Paris, France, p. 5-6.

5. N'dia KF, Bléyéré NM, Kouakou KL, Abo KJC, Yapo AP, et al. (2013a) Acute toxicity in mice and effects of a butanol extract from the leaves of Blighia unijugata Bak. (Sapindaceae) on electrocardiogram of Rabbits. Scholars Academic Journal of Pharmacy 2(6): 429-435.

6. N'dia KF, Kouakou KL, Bléyéré NM, Yapo AP, Ehilé EE (2013b) Hypotensive effects of a butanol active fraction from leaves of Blighia unijugata Bak. (Sapindaceae) on arterial blood pressure of rabbit. World Journal of Pharmacy and Pharmaceutical Sciences 2(6): 6693-6705.

7. N'dia KF (2015) Effets pharmacologiques et physiologiques d'extraits de Blighia unijugata Bak. (Sapindaceae) chez des mammifères (lapins, rats, souris). Thèse unique, Université Nangui Abrogoua, Abidjan (Côte d'Ivoire), pp. 184

8. Aké Assi L (2002) Boissiera 58. Flore de la Côte d'Ivoire : catalogue systématique, biogéographie et écologie II. Mémoires de botanique systématique, pp. 117-124

9. (1998) OCDE (1998) Série sur les principes de bonnes pratiques de laboratoire et vérification du respect de ces principes. ENV/MC/CHEM 98(17): 22-23.

10. N'dia KF, Traoré F, Kouakou KL, Ehilé EE (2009) Effets pharmacologiques d'un extrait aqueux de Mirabilis jalapa L (Nyctaginaceae) sur le système cardiovasculaire, la respiration et l'activité mécanique intestinale de mammifères. Afrique Science 5(2): 330-348.

11.Guédé-Guina F, Vangah MM, Harouna D, Bahi C (1993) Potencies of Misca, a plant source concentrate against fungi.J Ethnopharmacol 14(2): $45-53$

12. Kéita AA, Mariko E, Haïdara TK (1998) Etude de l’activitéhypoglycémiante des feuilles de Sclerocarya birrea (A. Rich.) Hochst. (Anacardiaceae). Pharm Méd Trad Afr 10: 16-25.

13. Sakandé J, Nacoulma OG, Nikiéma JB, Lompo M, Bassené E, et al. (2004) Etude de l'effet antipyrétique d'extraits des inflorescences mâles du rônier Borassus aethiopum Mart (Arecaceae). Méd Afr N 51(5): 280-282.

14.Zirihi GN, Kra AKM, Bahi C, Guédé-Guina F (2003) Plantes médicinales immuno stimulantes : critères de sélection, techniques rapides d'extraction des principes actifs et méthodes d'évaluation de l'activité immunogène. Rev Pharm Afr 17: 131-138.

15. Watcho P, Nchegang B, Nguelefack TB, Kamanyi A (2010) Evaluation des effets prosexuels des extraits de Bridelia ferruginea chez le rat mâle naïf. Androl 20(3): 209-215.

16. Waynforth BH (1980) Injection Techniques-Experimental and Surgical Techniques in the Rat. Academic Press, London, p. 3-61.

17. Jones W, Mohr H (1990) Hemopoietic system-Springer Verlag. Lea \& Febliger, Philadelphia 9: 149-154.

18. Lima LB, Vasconcelos CFB, Maranhão HML, Leite VR, Ferreira PA, et al. (2009) Acute and subacute toxicity of Schinus terebinthifolius bark extract. J Ethnopharmacol 126(3): 468-473.

19. Tietz NW, Prude EL, Sirgard-Anderson O (1994) Tietz textbook of clinical chemistry (2 ${ }^{\text {nd }}$ Edn.)., WB Saunders Company, London, pp. 1354-1374.

20. Young DS (1997) Effects of Drugs on Clinical Laboratory Tests. Annals of Clinical Biochemistry 34(6): 579-581. 
21. Friewald WT, Levy RI, Fredrickson DS (1972) Estimation of the Concentration of Low Density Lipoprotein Cholesterol in Plasma without the use of Preparative Ultracentrifuge. Clinical Chemistry 18(6): 499-502.

22. Pearlman FC, Lee RTY (1974) Detection and measurement of total bilirubin in serum, with use of surfactants as solubilizing agents. Clin Chem 20(4): 447-453.

23. Zoppi F, Peracino A, Fenili D, Marcovina S, Ramella C (1976) Metodo per la determinazione della bilirubina totale e coniugata. Uso di un tensioattivo cationico come agente solubilizzante. Giom It Chim $\mathrm{Cl}$ 1(1): 343-359.

24. Sasaki T, Matsy S, Sonae A (1972) Effect of acetic acid concentration on the color reaction in the 0 -toludine boric acid method for blood glucose estimation. Rinsho Kagaku 1(3): 346-353.

25. Gindler ME, Heth DA (1971) Colorimetric determination with bound «Calmagite» of magnesium in human blood serum. Clin Chem 17(7): 662.

26. Michaylova V, Illkova P (1971) Photometric determination of micro amounts of calcium with Arsenazo III. Anal Chim Acta 53(1): 194-198.

27. Tietz NW (1976) Fundamentals of clinical chemistry. Ed. WB. Saunders Co Philadelphia 2(11): 875-877.

28. Tietz NW (1987) Fundamentals of clinical chemistry. Ed. WB. Saunders Co Philadelphia 2: 426-428.

29. Panagiotakos B, Pitsavos C, Skoumas J, Chrysohou C, Toutouza $\mathrm{M}$, et al. (2003) Importance of LDL/HDL ratio as a predicator for coronary heart disease events in patients with heterozygous familial hypercholesterolemia: A 15-year follow-up (1987-2002). Curr Med Res Opin 19(2): 89-94.

30. Yakubu MT, Akanji MA, Oladiji AT (2007) Haematological evaluation in male albino. Rats following chronic administration of aqueous extract of Fadogia argrestis stem. Pharmacog Mag 3(9): 34-38.

31. Olson H, Betton G, Robinson D, Thomas K, Monro A, et al. (2000) Concordance of toxicity of pharmaceuticals in humans and in animals Regul Toxicol Pharmacol 32(1): 56-67.

32. Etame Loe G, Dibong SD, Yinyang J, Elimbi M, Ngoule CC, et al. (2018) Étude de la toxicité aigüe et subaigüe de l'extrait au vin de palme des rhizomes de Curcuma longa Linn. Journal of Applied Biosciences 132: 13452-13460.

33. Varley H (1975) Practical clinical chemistry (4 $4^{\text {th }}$ Edn.)., ArnoldHeinemann publishers, India, pp. 350-363.

34. Shanker K, Pathak NKR, Trivedi VP, Chansuria JPN, Pandey VB (2002) An evaluation of toxicity of Taxus baccata Linn. (Talispatra) in experimental animals. J Ethnopharmacol 79(1): 69-73.

35. Ramaiah SK (2011) Preclinical safety assessment : current gaps, challenges, and approaches in identifying translatable biomarkers of drug-induced liver injury. Clinics in Laboratory Medicine 31(1): 161172.

36. Aïssatou DS, Metsagang JTN, Sokeng CD, Njintang NY (2017) Anthihyperlipidemic and hypolipidimic properties of Tacca leontopetaloides (L) Kuntze (Discoreales : Discoreaceae) tuber's aqueous extracts in the rats. Brizilian Journal of Biological Sciences 4(7): 67-80.

37. Akanmu MA, Adeloye AO, Obuotor EM, Adelusola KA, Iwalewa EO, et al. (2010) Acute and Sub-Chronic Toxicity Potential Effects of Alchornea cordifolia (Euphorbiaceae) in Rats. Nigerian Journal of Natural Products and Medicine 14(1): 14-20.
38. Ajibade TO, Olayemi FO (2015) Reproductive and toxic effects of methanol extract of Alchornea cordifolia leaf in male rats. Andrologia 47(9): 1034-1040.

39. Gatsing D, Aliyu R, Kuiate JR, Garba IH, Jaryum KH, et al. (2005) Toxicological evaluation of the aqueous extract of Allium sativum bulbs on laboratory mice and rats. Cameroun J Exp Biol 1(1): 39-45.

40. Shahjahan M, Sabitha KE, Jamu M, Shyamala Dev CS (2004) Effect of Solanum trilobatum against carbon tetrachloride induced hepatic damage in albino rats. Indian J Med Res 120(3): 194-198.

41. Ashafa AOT, Yakubu MT, Grierson DS, Afolayan AJ (2009a) Toxicological evaluation of the aqueous extract of Felicia muricata Thunb. Leaves in Wistar rats. Afr J Biotechnol 8(6): 949-954.

42.Zarzuelo A, Jimenez I, Gamez MJ (1996) Effects of luteolin 5-0-betarutenoside in streptozotocin-induced diabetic rats. Life Sci 58(25): 2311-2316.

43. Nojima H, Kimura I, Chen FJ (1998) Anti-hyperglycemic effects of $\mathrm{N}$-containing sugars from Xanthocercis zambesiaca, Morus bombycis, Aglaonema trubii and Castanosperrmi australe in streptozotocindiabetic mice. J Nat Prod 61(3): 397-400.

44. Kim HY, Moon BH, Lee HJ, Choi DH (2004) Flavonoids glycosides from the leaves of Eucommia ulmoides with gyration inhibitory activity. J Ethnopharmacol 93(2-3): 227-230.

45. Reher G, Slijepcevic M, Krans L (1991) Hypoglycemic activity of triterpenes and tannins from Sarcopoterium spinosum and two Sanguisorba Species. Planta Med 57(8): 57-58.

46. Kako M, Miura T, Nishiyama Y, Icchimaru M, Mariyasu M, et al. (1997) Hypoglycemic activity of some triterpenoid glycosides. J Nat Prod 60(6): 604-605.

47. Kumar KA, Maheswari MU, Sivashanmugam AT (2007) Hypoglycemic effects of Ficus microcarpa leaves (Chinese Baryan) on alloxan-induced diabetic rats. J Biol Sci 7(2): 321-326.

48. Olorunnisola DS, Amao IS, Ehigie DO, Ajayi ZAF (2008) Antihyperglycemic and hypoglycemic effect of ethanolic extract of Chrysophyllum albidum seed cotyledon in alloxan induced-diabetic rats. Res. J Applied Sci 3(2): 123-127.

49. Adebayo AH, Abolaji AO, Opata TK, Adegbenro IK (2010) Effects of ethanolic leaf of Chrysophyllum albidum G. on biochemical and haematological parameters of albino Wistar rats. Afr J Biotechnol 9(14): 2145-2150.

50. Keita H, Dos Santos CBR, Ramos MM, Padilha EL, Serafim RB, et al. (2021) Assesment of the hypoglycemic effect of Bixin in alloxan-induced diabetic rats: in vivo and in silico studies. Journal of Biomolecular Structure and Dynamics 39(3): 1017-1028.

51. Sakandé J, Ahiboh H, Edjeme A, Yapo AE (2003) Etude de la tolérance biologique d'une plante à activité antiplasmodiale: Momordica charantia L. (Cucurbitaceae). Mali Médical, XVIII (1\&2): 1-4.

52. Kaplan LA, Szabo LL, Opherin EK (1988) Clinical chemistry: Interpretation and techniques ( $3^{\text {rd }}$ Edn.)., Lea \& Febliger, Philadelphia, pp. 112-231.

53. Aliyu R, Adebayo AH, Gatsing D, Garba IH (2007) The effects of ethanolic leaf extract of Commiphora africana (Burseraceae) on rat liver and kidney functions. J Pharmacol Toxicol 2(4): 373-379.

54. Nduka N (1999) Clinical biochemistry for students of pathology. Amino Press Ltd, Nigeria, pp. 142-143.

55. Jimoh FO, Adepapo AA, Sofidiya MO, Masika PJ, Afolayan AJ (2008) Safety evaluation of the extract from the shoots of Arctotis arctotoides in rats and mice. Afr J Biotechnol 7(18): 3173-3177. 
56. Philip DM (1995) Plasma enzyme in diagnosis. In: Clinical chemistry in diagnosis and treatment ( $6^{\text {th }}$ Edn.)., Arnold Publishers, London, pp. 303307.

57. Mayes PA (1996) Lipid transport and storage (24 ${ }^{\text {th }}$ Edn.).,. In: Harper's biochemistry. Murray RK., Granner DK., Mayes PA, Rodwell VW (Eds.). Prentice Hall International, USA, pp. 254-255.

58. Oyebanji BO, Oridupa OA, Ajibade TO, Saba AB (2015) Effect of SubChronic Administration of Tetracera potatoria Roots Extract and
Betulinic Acid from the Plant on Haematology and Serum Biochemistry of Wistar Rats. Nigerian Veterinary Journal 36(1): 1144-1153.

59. Ashafa AOT, Yakubu MT, Grierson DS, Afolayan AJ (2009b) Effects of aqueous extract from the leaves of Chrysocoma ciliata L. on some biochemical parameters of Wistar rats. Afr J Biotechnol 8(8): 1425-1430.

60. Abolaji AO, Adebayo AH, Odesanni OS (2007) Effect of ethanolic extract of Parinari polyandra (Rosaceae) on serum lipid profile and some electrolytes in pregnant rabbits. Res J Med Plants 1(4): 121-127.
ISSN: 2574-1241

DOI: 10.26717/BJSTR.2021.40.006440

N’DIA Kouadio Frédéric. Biomed J Sci \& Tech Res

(C) (P) This work is licensed under Creative

Submission Link: https://biomedres.us/submit-manuscript.php

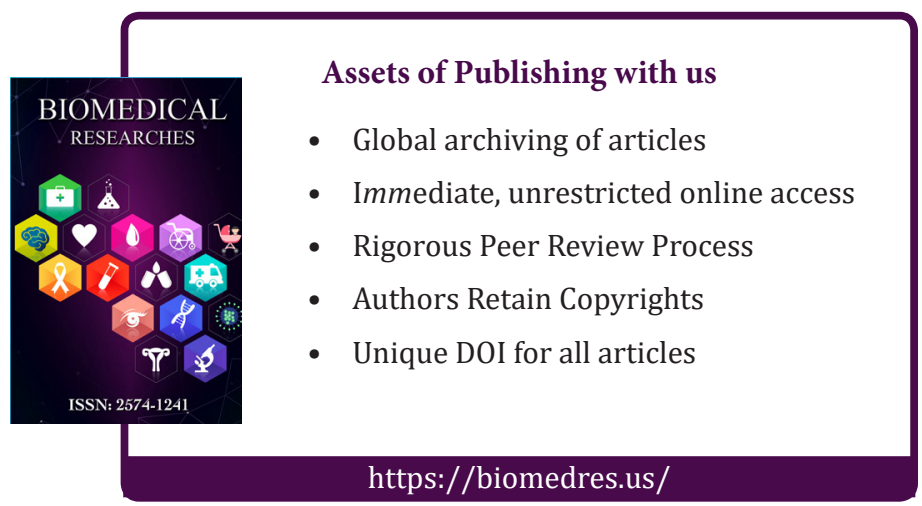

